\title{
SYMPOSIUM ON INTERNATIONAL INDIGENOUS RIGHTS, FINANCIAL DECISIONS, AND LOCAL POLICY
}

\author{
INDIGENOUS PEOPLES, INTERNATIONAL LAW, \\ AND EXTRACTIVE INDUSTRY CONTRACTS
}

Ibironke T. Odumosu-Ayanu*

\section{Introduction}

The extractive industry has contributed to the development of international law since colonial times. Contracts between states and extractive companies largely drive this global industry. This essay situates extractive industry contracts involving Indigenous peoples, long term actors who have significantly informed the development of international law, within the context of international law. While these contracts are usually analyzed from domestic perspectives, they are impacted by international norms and, as developing transnational practices, even have the potential to show ways ahead in international law. As regards engagement with Indigenous peoples, contracts, which are typically regarded as private instruments, have significant public ramifications. This is especially the case where states, Indigenous peoples, and transnational corporations (TNCs) are involved and where internationally recognized principles relating to Indigenous rights, notably free, prior, and informed consent (FPIC) are implicated.

Political philosophers have debated the meaning of consent for centuries. Consent is especially problematic within the context of an international law framed by colonial relations. ${ }^{1}$ The norm of FPIC emerging in international law seeks to capture Indigenous peoples' decision-making rights as part of the right to selfdetermination. Some states interpret FPIC as conferring a veto on Indigenous peoples; hence these states' objections to FPIC. ${ }^{2}$ Meanwhile, extractive industry(-related) contracts that involve Indigenous peoples as parties have the potential to foster negotiation and amicable interpretations of FPIC that ensure that the rights of Indigenous peoples are not violated. As the Special Rapporteur on the Rights of Indigenous Peoples noted in

\footnotetext{
* Associate Professor, College of Law, University of Saskatchewan. Thanks to the Social Sciences and Humanities Research Council (Canada) for funding my research on local communities and extractive industry contracts, to the Law Foundation of Saskatchewan for funding parts of the research presented in this essay and to Dwight Newman and Karen Knop for comments on earlier drafts.

Originally published online 14 January 2016.

${ }^{1}$ Jeremy Webber, The Meanings of Consent, in Between Consenting Peoples: Political Community and the Meaning of ConSENT 3, 5 (Jeremy Webber \& Colin M. Macleod eds., 2010).

2 See Cathal M. Doyle, Indigenous Peoples, Title to Territory, Rights and Resources: The Transformative Role of FREE PRIOR AND INFORMED CONSENT 161-168 (2015).
}

ASIL and Ibironke T. Odumosu-Ayanu @ 2016 
2009, "the principles of consultation and consent are aimed at avoiding the imposition of the will of one party over the other, and at instead striving for mutual understanding and consensual decision-making." 3

Some commentators and organizations, including the International Finance Corporation (IFC), advocate various forms of agreements/contracts as a means of effecting FPIC. ${ }^{4}$ This essay demonstrates that, in practice, some Indigenous communities have been more extensively involved in contract frameworks than the proposals by organizations such as the IFC contemplate. ${ }^{5}$ In this light, it explores the practical implications of FPIC as a "regime of negotiated justice." I use the term "negotiated justice" to refer to contracts that define the terms of engagement by and with Indigenous peoples and situate extractive contracts within internationally recognized principles that foster Indigenous peoples' rights, especially FPIC, as enunciated in the United Nations Declaration on the Rights of Indigenous Peoples (UNDRIP). ${ }^{7}$

\section{Indigenous Peoples and Extractive Industry(-Related) Contracts}

Indigenous peoples' participation in forming various agreements with nonindigenous actors is not a new phenomenon. In fact, UNDRIP includes multiple references to treaties and agreements between Indigenous peoples and states. ${ }^{8}$ During precolonial/colonial times, Indigenous peoples formed a number of treaties with colonizers based on their capacity to consent to engagement with other nations. However, the colonial encounter facilitated a simultaneous dispossession of Indigenous peoples and development of international law. ${ }^{9}$ Attention to the historical results of consent during the colonial era makes some questions regarding and a critical approach to the consent-based engagement of Indigenous peoples in a neoliberal global extractive industry necessary. Nevertheless, while international law facilitated domination and dispossession through the colonial encounter, it retains some ability to reverse effects of domination; hence Indigenous peoples' turn to the international legal system in resistance to and engagement with dominant economic and political systems.

In contemporary extractive industry governance, Indigenous peoples have retained negotiation with nonindigenous actors as one of the means by which they engage. As the Special Rapporteur on the Rights of Indigenous Peoples notes, "direct negotiations between companies and indigenous peoples may be the most efficient and desirable way of arriving at agreed-upon arrangements for extraction of natural resources within indigenous territories that are fully respectful of indigenous peoples' rights, and they may provide indigenous peoples opportunities to pursue their own development priorities."10 Contracts are one example of "agreedupon arrangements" between Indigenous peoples and companies.

\footnotetext{
${ }^{3}$ James Anaya (Special Rapporteur on the Situation of Human Rights and Fundamental Freedoms of Indigenous People), Promotion and Protection of All Human Rights, Civil, Political, Economic, Social and Cultural Rights, including the Right to Development, UN Doc. A/HRC/12/34 (July 15, 2009).

4 See International Finance Corporation, Guidance Notes: Performance Standards on Environmental and Social Sustainability, Guidance Note 7, Indigenous Peoples, para GN38 (2012); Shalanda Baker, Why the IFC's Free, Prior and Informed Consent Policy does not Matter (Yet) to Indigenous Communities Affected by Development Projects, 30 WIS. INT'L L.J. 668, 671, 695-703 (2013).

5 International Finance Corporation, supra note 4.

${ }^{6}$ David Szablowski, Operationalizing Free, Prior, and Informed Consent in the Extractive Industry Sector?: Examining the Challenges of a Negotiated Model of Justice, 30 CAN. J. Dev. STUD. 111, 112 (2010).

7 See, e.g., Declaration on the Rights of Indigenous Peoples, GA Res. 61/295 art. 32(2) (Sept. 13, 2007). See also, International Labor Organization Indigenous and Tribal Peoples Convention arts. 6, 15, 16, June 27, 1989, 28 ILM 1282.

8 See, e.g., Declaration on the Rights of Indigenous Peoples, GA Res. 61/295 prmbl., art. 37 (Sept. 13, 2007).

9 ANTONY ANGHIE, IMPERIALISM, SOVEREIGNTY AND THE MAKING OF INTERNATIONAL LAW 15 (2005).

${ }^{10}$ James Anaya (Special Rapporteur on the Rights of Indigenous Peoples), Extractive Industries and Indigenous Peoples, para. 61, UN Doc. A/HRC/24/41 (July 1, 2013).
} 
However some contracts, especially Community Development Agreements (including Impact and Benefits Agreements formed between Indigenous peoples and extractive companies in Canada), sometimes exemplify situations where Indigenous consent is "sought but not required." 11 One commentator has noted that "far from being examples of free, prior and informed consent which includes the rights of communities to say 'no' to a development, Impact Benefit Agreements involve community consent to accrue certain benefits from a development which they might fundamentally disagree with, and to try to mitigate impacts. They are one means for Indigenous Peoples to try to protect their land as best possible given a development going ahead."12

Whether modern contracts involving Indigenous peoples adopt some interpretation of FPIC depends on at least three factors, that is, the nature and scope of the contracts, the process of acquiring and the manifestations of Indigenous peoples' consent, and Indigenous understandings of agreements and relationship. The nature of a contract and its scope could demonstrate the extent of Indigenous peoples' involvement in determinative decision-making regarding a project, contract-making processes are instrumental in determining consent, and the extent to which parties' varying interpretations of issues are incorporated into contracts could illustrate that negotiation has led to agreement. Indeed, the nature and scope of a contract could determine the extent of its impact and could also indicate whether Indigenous peoples' consent to a project, based on their interpretation of the relevant issues, is present.

\section{The Nature and Scope of Contracts}

Most extractive industry(-related) contracts that involve Indigenous communities are not definitive instruments that determine the scope, duration, and operation of extractive projects. They are mostly contracts that focus on aspects of natural resource extraction that could impact Indigenous communities rather than defining the framework for the projects. Some of the relevant contracts that directly involve Indigenous communities include exploration contracts, joint venture agreements, environmental contracts, and community development agreements (CDAs). ${ }^{13} \mathrm{CDAs}$ are perhaps the most prevalent of these contracts. ${ }^{14} \mathrm{CDAs}$ are "an emerging global phenomenon" covering an increasing scope of issues. ${ }^{15}$ These issues range from employment, education and scholarships, and revenue allocation to environmental impacts. ${ }^{16}$ Although they are being negotiated all over the world by local communities, there are also implications and challenges to forming CDAs including restrictions on access to legal opportunities that communities would otherwise have. ${ }^{17}$ Given their adoption from Canada to Ghana and from Papua New Guinea to Australia and Nigeria, the balance of this essay focuses on CDAs, specifically Canada's Impact and Benefit Agreements (IBAs)..$^{18}$

11 Szablowski, supra note 6, at 117.

12 Viviane Weitzner, “Dealing Full Force”: Lutsel K’e Dene First Nation's Experience Negotiating With Mining COMPANIES 30 (2006).

${ }^{13}$ James Gathii \& Ibironke T. Odumosu-Ayanu, The Turn to Contractual Responsibility in the Global Extractive Industry, 1 Bus. \& Hum. RTS. J. 69 (2015).

${ }^{14}$ Ciaran O'Faircheallaigh, Community Development Agreements in the Mining Industry: An Emerging Global Phenomenon, 44 COMmUNiTY DEv. 222 (2013).

$15 \underline{I d}$.

$16 \underline{I d}$. at 228 .

${ }_{17}$ Ciaran O'Faircheallaigh, Aboriginal-Mining Company Contractual Agreements in Australia and Canada: Implications for Political Autonomy and Community Development, 30 CAN. J. DEv. STUD. 69, 75 (2010).

${ }^{18} \mathrm{CDAs}$ are known by different terms around the world — in Canada they are mostly referred to as Impact and Benefit Agreements. Ibironke T. Odumosu-Ayanu, Governments, Investors and Local Communities: Analysis of a Multi-Actor Investment Contract Framework, 15 Melbourne J. InT'L L. 473 (2014) [hereinafter Odumosu-Ayanu, Governments, Investors and Local Communities]; Ibironke T. OdumosuAyanu, Foreign Direct Investment Catalysts in West Africa: Interactions with Local Content Laws and Industry-Community Agreements, 35 N.C. CENT. 
IBAs in Canada are mostly "privately negotiated agreements" typically formed between Indigenous communities and extractive companies. ${ }^{19}$ They may be required in Land Claims Agreements between Indigenous peoples and the Canadian Government, ${ }^{20}$ form part of the consultation process for extractive projects or be voluntarily negotiated. ${ }^{21}$ It appears that IBAs in Canada are influenced by the prevailing Canadian consultation model $^{22}$ which, in its tendency to focus on consultation and attendant factors, is more akin to that of ILO Convention 169 than to a consent model following the FPIC principles enunciated in the UNDRIP.

IBAs generally do not define the main aspects of a project even though they may express Indigenous support for a project. ${ }^{23}$ So even though they are, perhaps, the most common contractual instrument to which Indigenous peoples are parties in the extractive industries and they have the potential to provide significant benefits to Indigenous peoples if the challenges are effectively mitigated, IBAs are mostly not designed as principal extractive instruments. This does not however suggest that IBAs do not have the potential to respond to some crucial issues including the remedial challenges that international law has faced with regard to TNC accountability. 24

\section{Indigenous Consent and Extractive Industry Contracts}

The extent to which an IBA mirrors Indigenous peoples' consent to a project varies and could depend on the terms of the agreement, the timing of formation of the agreement, and the circumstances surrounding formation. Even though they are mostly instruments that detail extractive companies' commitments to provide benefits to communities and in some cases mitigate impacts, some IBAs include provisions that suggest that communities trade their support (consent?) for projects for these benefits. Article 5 of the Collaboration Agreement between the Northern Village of Pinehouse and Kineepik Metis Local Inc. and Cameco Corporation and Areva Resources Canada Inc. ("Pinehouse Agreement") outlines Pinehouse's "explicit support" for Cameco and Areva's operations. ${ }^{25}$

The Pinehouse Agreement includes consent-like terms and also raises issues regarding timing. The support provisions extend to existing, proposed and exploration projects. However, the extensive provisions of article 5 , which is over three pages long, do not clearly articulate the place of the community's continuing support for proposed and exploration projects in the face of subsequently available detailed information. In addition, although section 5.1(a) provides that "Pinehouse acknowledges in general that it has been consulted over the course of many years in relation to the Existing Operations," it does not necessarily follow that the community gave consent prior to the commencement of existing operations.

L. REv. 65, 80-87 (2013). For different terminologies for IBAs in Canada, see Janet Keeping, Thinking about Benefits Agreements: An Analytical Framework, Northern Minerals Program Working Paper No. 4, 2-5 (1998).

${ }^{19}$ Ken J. Caine and Naomi Krogman, Powerful or Just Plain Power-Full? A Power Analysis of Impact and Benefit Agreements in Canada's North, 23 ORG. \& ENV'T 76, 77 (2010).

${ }^{20}$ Agreement between the Inuit of the Nunavut Settlement Area and Her Majesty the Queen in Right of Canada section 26, May 25, 1993.

21 Odumosu-Ayanu, Governments, Investors and Local Communities, supra note 18, at 488-491.

22 On the duty to consult, see Dwight G. Newman, Revisiting the Duty to Consult Aboriginal Peoples (2014).

${ }^{23}$ For contents of IBAs, see Odumosu-Ayanu, Governments, Investors and Local Communities, supra note 18, at 489.

24 See Gathii \& Odumosu-Ayanu, supra note 13.

${ }^{25}$ Collaboration Agreement between the Northern Village of Pinehouse and Kineepik Metis Local Inc. and Cameco Corporation and Areva Resources Canada Inc., December 12, 2012. See also, Draft Raglan Agreement entered into between Makivik Corporation, Qarqalik Landholding Corporation of Salluit, Northern Village Corporation of Salluit, Nunatulik Landholding Corporation of Kangiqsujuaq, Northern Village Corporation of Kangiqsujuaq and Societe Miniere Raglan du Quebec Ltee (to which intervened Falconbridge Limited) sections 2.1.6, 7.1(c), Jan. 25, 1995. 
The circumstances under which IBAs are negotiated also have implications for communities' consent. The IBA formation process for the Ekati diamond mine project in Canada, for example, was impacted inter alia by "a lack of information and very short timelines" and it has been argued that the Indigenous peoples "understood that they would not be allowed to reject the Ekati project by withdrawing from IBA negotiations." 26 Essentially, the fact that IBAs are formed does not necessarily mean that communities have freely granted consent with full information about the ramifications of a project. Some specific agreements could, however, respond to consent issues. In this regard, it has been reported that Energy Resources of Australia, a part of the Rio Tinto group, entered into the Jabiluka Long Term Care and Maintenance Agreement with the Mirrar Traditional Owners in which the company agreed not to conduct future developments without the consent of the traditional owners. ${ }^{27}$

\section{Indigenous Perspectives and Interpretation}

The views of contract law that dominate extractive projects are mostly based on a capitalist neoliberal framework that communities often challenge. Indigenous perspectives and understandings of agreements are essential to contracts that purport to reflect the standards that Indigenous peoples have argued for in international law. As the Inter-American Court of Human Rights stated in the Case of the Saramaka People v. Suriname, consultation needs to be according to peoples "customs and traditions." 28 In addition, where "large scale development or investment projects ... would have a major impact" the State has a duty to consult and also to obtain the peoples "free, prior, and informed consent, according to their customs and traditions." 29 If contracts are to meet these standards, they should be informed by Indigenous understandings of agreement and relationship. The same must be true for both domestic and international law which must transcend state, international organization, and TNC interpretations of concepts, instruments, and relationships.

Furthermore, in order for contracts that involve Indigenous peoples to foster the development of and/or comply with legal regimes that take Indigenous rights to self-determination seriously, those instruments would need to recognize the "considerable potential for cross-cultural understanding (and indeed, learning) and for cross-cultural community." ${ }^{30}$ In this regard, UNDRIP's preamble recognizes that "respect for indigenous knowledge, cultures and traditional practices contributes to sustainable and equitable development and proper management of the environment." If CDAs and other extractive industry(-related) contracts subsume Indigenous knowledge and practices within western legal traditions in a manner that erases the unique contributions of such "knowledge, cultures and traditional practices," these contracts assume the position of limited instruments. They remain instruments that may not adequately reflect the positions of the contracting parties who may differ significantly on issues such as environmental management and dispute resolution.

This is the age of contracts in the engagement between some Indigenous peoples and the global extractive industry. Detailed study and analysis of these contracts is necessary as agreement-making historically coexisted

26 Szablowski, supra note 6, at 117.

27 See ANTS, Jabiluka Long-Term Care and Maintenance Agreement; Australian Government, Department of Environment, $\underline{\text { Ura- }}$ nium Mining in the Alligator Rivers Region; Energy Resources of Australia, Business Overview.

${ }^{28}$ Case of the Saramaka People v. Suriname, Preliminary Objections, Merits, Reparations and Costs, Judgment, Inter-Am. Ct. H.R. (ser. C) No. 172, para. 133 (Nov. 28, 2007).

${ }^{29} \underline{I d}$. at para. 134 (emphasis added).

${ }^{30}$ Webber, supra note 1 , at 34 . 
with colonialism and the development of international law. State-investor extractive industry contracts were also crucial to the development of international law during the decolonization era of the 1950s and 1960s. In spite of the challenges that both international law and agreement-making have presented for colonized peoples, Indigenous peoples, like Third World states, have retained international law as a site for reversing unfavourable legal norms, and they have also been active in forming some contracts in the extractive industries. Contracts are being adopted as instruments for responding to some international law principles regarding Indigenous self-determination, but they also have significant implications for international law. Not only will advances in international law continue to inform Indigenous participation in contracts but these contracts may also lead to advances beyond international law's present standards.

If Indigenous peoples continue to adopt contracts as a mechanism for engaging in extractive industries, it is necessary firstly to consider contracts that exceed the specific issues that have formed the prevalent focus of this engagement and address fundamental issues that demonstrate that Indigenous peoples consent to an extractive project. Secondly, contracts with Indigenous peoples that effectively encompass their self-determination and consent rights are likely to be more effective if both states and industry actors are parties so that all the core parties are represented within a single contract regime. Thirdly, parties that give consent to an activity are often interested in the remedial measures that are available. Here, Indigenous peoples-involved contracts have the potential to respond to challenges that international law faces regarding TNC accountability and remedies, as well as state responsibility to Indigenous peoples. The development of such contracting practices could further move international law in directions that it has yet to approach. 